\title{
Historical Thinking Skills among Pre-Service Teachers in Indonesia and Malaysia
}

\author{
Mohd Mahzan Awang, Abdul Razaq Ahmad, Noria Munirah Yakub, Ahmad Ali Seman \\ Faculty of Education, National University of Malaysia, UKM Bangi, Selangor, Malaysia \\ Email:mahzan@ukm.edu.my,razaq@ukm.edu.my,zhafirahmunirah@gmail.com, aasw@ukm.edu.my
}

Received 25 November 2015; accepted 22 January 2016; published 25 January 2016

Copyright (C) 2016 by authors and Scientific Research Publishing Inc.

This work is licensed under the Creative Commons Attribution International License (CC BY).

http://creativecommons.org/licenses/by/4.0/

(c) (i) Open Access

\section{Abstract}

This comparative study examined student thinking skills and their attitudes towards learning History. Respondents were pre-service teachers who enrolled in the History Education Program from two education universities in Malaysia and Indonesia. The historical thinking skills (HTS) and their attitudes examined in this study are: chronological skills, facts exploration skills, imagination skills, interpretation skills and rationalization skills. A set of questionnaire was used to gain data. Data analyses involved descriptive and inferential analysis. A Cronbach Alpha score obtained from a pilot indicated that all constructs were at a high reliability level (between 0.73 and 0.89 ). Data collection was carried out in Malaysia and Indonesia involving 260 respondents. The results of this study demonstrated that there was a high level of Historical Thinking Skills (HTS) among teacher trainees from both countries. Detailed result indicated that Malaysian teachers have a higher level of the following historical thinking skills: facts exploration, interpretation skills and rationalization. However, results show that that none of these historical skills have statistically differences. This means that historical skills among teachers in both countries are similar. Overall, the current study suggests intensive training to promote historical thinking skills among teacher trainees from both countries. Implication towards teaching practices is discussed.

\section{Keywords}

Historical Thinking Skills, Trainee Teachers, History Education, Higher Education Institution

\section{Introduction}

Extensive past research suggests the importance of civic and national involvement among young generation. It is a pillar for a country development. In a study of young people involvement in civic activities, Schulze (2014) found that most young people had low self-esteem, lack of patriotism and poor knowledge on national issues. In 
a study on the same subject in Malaysia, Mansor (2011) realized that history education is important for improving patriotic values among nation. Knowing history education and knowledge will influence positive changes in the attitude of the young people, many countries have been focusing on history education in the school curriculum in order to reshape students' strong personality and to improve their patriotic spirit. Consequently, it is the responsibility of the History teachers to deliver the curriculum and improve their ability to carry out effective instructional process. Previous studies (Adams, King, \& King, 1996; Awang, Ahmad, \& Ali, 2013) showed that effective instructional process was very much depending on teachers' personality and capability in creating interesting and effective learning experience for the students.

It is important to attract students to the History lesson by introducing clear historical concept such as the cause and effects, chronological events and interpretation skills. This can be done via providing students with appropriate examples which are related to students' previous knowledge and experience. Education is not only teaching the students what they should know but also a platform for the students learning to know as well as learning to live together (Kim, 2014). History subject is a wealth of values and about humanity; hence there are countless questions and thinking steps to be explored. Learning History subject requires teachers' commitment in teaching by involving students' thinking skills, and the use of relevant multimedia and stimulating teaching aids (Twells, 2015).

Learning involves a relationship between human aspects and social values as well as the changes evolve in the society. This is actually in line with the objective of History education which is to promote thinking competency based on fact findings, mastering of ideas and Historical methodology. It is essential to ensure that students understand the importance of having previous or background knowledge on the subject matters being discussed in order to intelligently correlate the subject matters using various perspectives. The students' understanding enables them to use historical knowledge to expand their thinking process (Ekecrantz, Parliden, \& Olsson, 2015). Besides applying theories, interpreting lesson contents and using visual aids, it is very important for teachers to stimulate students' thinking process in History class. Teachers should not depend solely on the text books while teaching History subject as they are required the ability to help students to understand and to explain the links between past events with the current and present reality.

Teaching History requires pedagogical skills and creativity. It can be carried out either in a classroom or out of the classroom. The History teacher should not only focus on the presentation of facts to his students but also teach the facts as a thinking map using situation in which students may be able to think critically and make a relation between two events (Eggan \& Kauchak, 2001). It also may be helpful for students if the teachers encourage students to take part in classroom activities actively (Awang, Ahmad, \& Ali, 2013). As a result, the teaching and learning History will be more interesting and may be able to attract students' interests in learning History. History subject stimulates thinking and promotes critical and analytical thinking process whereby student's mind undergoes historical thinking during the period of learning History subject (Sokolov, 2015). Aziz \& Azleena (2007) maintains that the teachers have to be responsible to expand and inculcate students' thinking process; and stimulate and expand students' thinking ability by using various methods and teaching techniques.

Ahmad, Awang, Seman, \& Abdullah (2013) argue that teachers should also be able to use the textbooks effectively. However, an effective History teacher should not depend so much on textbooks as the teacher should have in-depth understanding on historical facts as well as pedagogical knowledge. Teachers are also required to carry out lesson effectively via various techniques. History teacher is supposed to have good skills for promoting historical thinking in teaching History. For instance, Ekecrantz, Parliden, \& Olsson (2015) argue that students should be taught the concept of historical thinking in order to have new perception and mindset that History subject is not a static boring subject. Andrews \& Burke (2007) and Barton (2012) proposed that historical knowledge was about a deeper and richer historical knowledge and deeper understanding on the historical phenomena and events as well as how they actually happened instead of the ability to solely memorize and recall torturous dates, years, names and events.

\section{The Importance of Historical Thinking}

Wineburg (2001) points out that History is a wide area of study including political, societal aspects, technological development and etc. This leads to various interpretations by many people. Hence, it is not necessary for a teacher to deliver every single fact and historical details to the students. In fact, the new era of historical thinking framework should be adopted by focusing on how to sharpen students' intellect by encouraging them to think 
critically and analytically (Jenkins, 1991).

History is interrelated and the thinking should be based on revealing the impacts of past actions taken by past governments or ancient societies on the present people. Many historians believe that the facts cannot explain themselves, hence it is teacher's responsibility to arouse curiosity, to infer and evaluate as well as to make own assumption on historical facts (Rohlf, 2015). This may be the best approach of history instructional process with regard to providing meanings for students. The inculcation of history thinking skills in the teaching and learning would make the History lesson to be fun and meaningful (Rohlf, 2015). This is in line with Dewey (1920), who maintains that learning is a meaningful process, with regards to the concept of learning by doing and at the same time helping students to think and develop their own understanding on certain issues and social phenomena.

Dewey's (1910) statement defines the concept of historical thinking which requires students to explore, to infer, to interpret, to imagine, to justify and to rationalize. This is actually related to teacher's ability to understand the structure of historical discipline as History education has a basic systematic structure of history discipline which involves the aspects of nation formation, development of nation state, modernized society and the essential parts of basic history and its universal expansion.

This is the true meaning of historical discussion and lessons provided for the current global citizens to learn from historical events. Due to the fact that historical events have powerful impacts on the way people are functioning now, many countries in the world are taking the efforts to uphold historic elements as the foundation in developing educational curriculum. Hence, it could conceivably be hypothesized that historic elements have clear impacts on the formation of nation character of a society.

Benjamin et al. (2013) in a recent study mentions that thinking skill is an interesting issue particularly among educators. This is due to the present development which needs teaching to be focused on the efforts to increase thinking skills. In addition, with abundance of new knowledge, people are now too information oriented, and have a stiff competition and demanding needs in life to produce quality human forces, and all of these require one to have the ability and capability in problem solving as well as decision making. In depth study shows that historical thinking skill refers to the knowledge of history discipline itself. The skill has to be promoted among students in order to help them to understand how historians reconstruct past events by simply using sources as evidences in determining significant dates, figures, locations and men's activities in the past. According to Brooks (2013), understanding and thinking of history would help teachers to interpret, investigate causes and effects and examine historical events in a wider context.

The objectives of this study are to examine the level of historical thinking skills among pre-service teachers of the History Education program, and to examine the implications of the thinking skills on the trainees' attitudes in implementing instructional process and realizing their roles as the mediators and facilitators to expand historical aspects. The key research question of this study was thus whether or not the teacher trainees, who are History subject curriculum interpreters, focus on the values and impacts of thinking skills and patriotism in developing the History subject.

\section{Components of Historical Thinking}

One of the main goals of education is to increase thinking skills. Schools and educational institutions are the best platforms to develop thinking skills. History subject is a subject which stimulates thinking. This subject allows students to analyze mankind emphatically and understand how people continuously are using time, spaces, and changes.

It is important to have a systematic strategy to encourage thinking process in History education. An effective history teacher uses integrated approach thinking skills to ensure his students are capable to master the contents and have the ability to undergo thinking process systematically using the contents of the subject.

Historical thinking refers to exploring evidences and the ability to criticize them; understanding the changes of time; and admitting that history is about the development and destruction of a nation or government. It is also about being emphatic about the past and to dig the reasons of certain events based on cause and effects. This idea supports Wineburg's (2001) definition that a unique way of thinking requires in-depth thinking, which is a natural process of psychological development. Past empirical study shows that historical thinking process will increase students intellectual ability, thus enables them to have better understanding on the current situation, simply by analyzing past events, which in the long run teaches students to plan their future (Swartz \& McGuness, 2014). In Malaysia, the historical thinking components are referred to the classification of history thinking (Ma- 
laysia Curriculum Development Centre, 2003). Since 2013, History becomes a compulsory subject for all students who are taking the national examination in Malaysia (Malaysia Certificate of Education). Upholding History subject as a core subject of the national education curriculum has been practiced in many developed countries including the United Kingdom, Germany, France, and the United State of America, Korea and Japan. In fact it is one of the reasons of high patriotic spirit among the youths and young generation of those countries. In Malaysian context, the historical thinking components consist of five aspects:

- Chronologic skills-the ability to arrange events chronologically;

- Facts exploration skills;

- Imagination skills;

- Interpretation and analyses skills; and

- Rationalizing skills.

\subsection{Chronologic Understanding}

Chronologic understanding refers to the process of arranging sequence of events or historical actions orderly to enable students to have a comprehensive understanding on the process of certain events from the beginning until the end. The common practice is teacher normally teaches students on how to use flow charts to describe events chronologically.

\subsection{Exploration of Evidences}

Students are allowed to explore evidences as they are exposed to primary and secondary sources; they also have to compare the two sources of information by digging more related information. This is an opportunity for students to appreciate every single historical evidence and refer to various relevant sources in order to find the truth, confirm and get answers for various questions. Students are taught to be historical researchers rather than being passive recipients.

\subsection{Interpretation}

Students are asked to analyze and interpret an event in order to help them understand the interrelation between historical facts. This skill requires systematic observation and interpretation to guide the society to have a better future life (Swartz \& McGuiness 2014). For instance, students are required to interpret the civilization concepts from the western and Islamic perspectives. The comparative study helps students to comparatively define, interpret and analyze the differences of views from two distinct perspectives.

\subsection{Imagination}

Imagination involves the use of mind and intellect to have a better judgment in solving a problem. Students should have the skills to gather data, make hypothesis, determine significant evidence and make inferences from a collected data. Those skills help students to get great knowledge from previous studies and this would help them to make better decision in the future (Sultan, 2000). Those five skills involve historical process or procedural skills from teachers and students. Teachers have to guide their students to link and relate past events with the present situation, analyze, research and process evidences, make hypothesis, understand and explain as well as come up with reasons.

\subsection{Rationalizing}

Rationalizing refers to the process of arranging sequence of events or historical actions orderly to enable students to comprehensively understand the process of certain events from the beginning until the end. The common practice is teacher normally teaches students on how to use flow charts.

\section{The Thinking Operation}

The Curriculum Development Centre (2002) defined thinking as a mental operation involving cognitive and meta-cognitive operations. Seixas (1996) claims that individuals who are exposed to the thinking process during their learning would normally make the right decision and take the right action based on situations and circums- 
tances. Thinking process is a mental operation resulting from observation, brainstorming, discussion, question and answer, intellectuality and exploration. During this process, the elements of mental operation used involve cognitive aspects, divergent thinking, convergent thinking, evaluation, recorded memories and expansion of memories. The use of stimulations and discussion strengthen students' expansion process in finding and exploring historical information.

The second link is the content where materials are discussed and learned by using concepts, facts and explanation. Benjafield (1992) explained that thinking skill comprises of three main components namely mental operation, knowledge and attitudes. Teachers should use several elements, such as visual maps, listening, words processing, symbols and behavioral changes, in helping students to have better understanding and the ability to get information.

\section{History Education in Malaysia and Indonesia}

History education was initially started in the Malay Land (currently known as Malaysia) since the middle of the $19^{\text {th }}$ century. History subject was added as part of the English school's curriculum in early $20^{\text {th }}$ century. From 1816 to 1957, the British History was the focus of study in the nation's (Malay Land) educational curriculum. In other words, the local history was ignored during the formation of curriculum for the History subject until the country achieved its independence. The British History education was more political in manner and was practically designed for the benefit of the British. It was indeed a diplomatic bridge between the British and the Malaya.

In the early 1918, the curriculum was then designed to focus on the local history. In 1912, the pioneer of History educators from the Sultan Idris Teaching College produced and published the first History text book, named as the Malay History. After the World War II, the Local History was given more attention when the education curriculum was revised (Noordin, 1993).

The History curriculum was designed to help students getting broader perspective on the evolution process of the world's civilization. Hence, the History curriculum was organized based on several themes. The events studied were very much related with the time whereas the patriotic elements in the History education concentrated on the values to serve the purpose of injecting pride as Malaysians. In addition, History education was also focused on inculcation of values to strengthen the nations' personalities. Patriotic elements consisted of the following elements namely a sense of pride being Malaysian citizens, love for the country, and a sense of belonging, well-discipline, hardworking and productive.

As far as the Integrated Curriculum for the secondary schools is concerned, it was the main channel to deliver the content of History curriculum as a group of information as well as an approach towards knowledge (KPM 1990). The History curriculum was later revised by concentrating on the integrated knowledge element (content), skills (structure for Historical thinking discipline) and inculcation of patriotic values in order to attain the objectives as stated by the syllabus (Figure 1).

History can be defined based on several aspects and criteria. Salleh (2003) defined history as 1) past events with historical objectives and true facts; 2) oratory stories told by trustworthy historians; 3) a branch or human social study which studies the community in terms of development, continuation, repetition as well as its evolution; and 4) a subjective art.

With respect to the Indonesian curriculum, it consists of past events; however not all historical stories can be defined as history. According to Kartodirdjo (1992), Indonesian history education curriculum is categorized into three phases: local history, national history and the world history. Local history covers various local stories including political, socio-economy, and cultural aspects, as well as the development and social mobility of societies in certain districts. It also covers local history of the old governments including the Srivijaya and Majapahit. National history is continuation of events happened at certain areas or districts which have significant impacts on other territories and the whole country. In other words, national history is interaction of local histories which have significant impacts such as the destruction of the Srivijaya's and Majapahit empires; and the fights for Independency in the year 1945.

International history covers historical events of other countries but they have significant implications internationally. The World War I, the World War II and Industrial Revolution are among the international events which added to the world's history. The policymakers revised the Indonesian education policy and divided the history curriculum into several themes: 


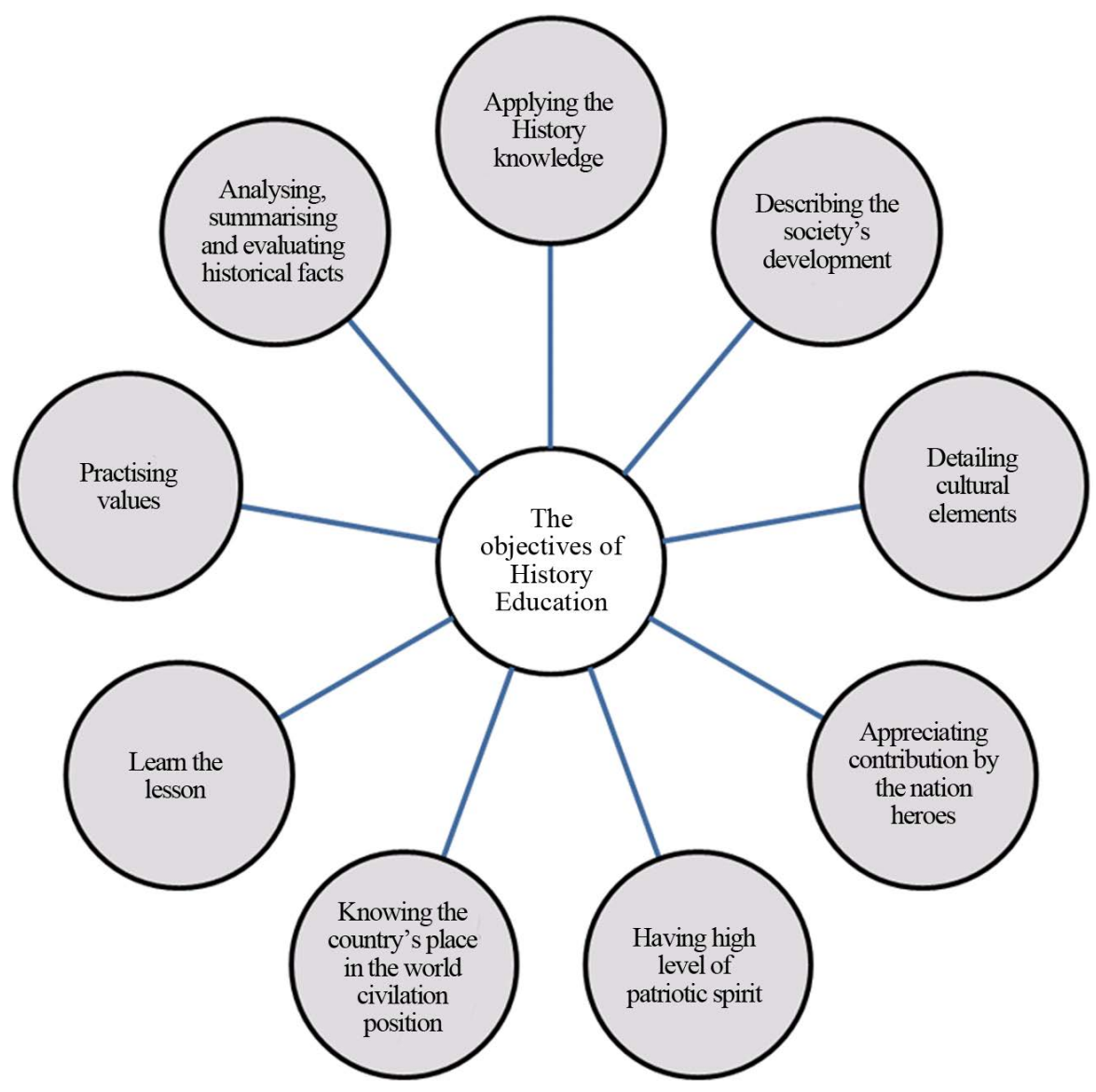

Figure 1. Objectives of history education.

- Political History;

- Social History;

- Economic History;

- Cultural History;

- Intellectual History.

In Indonesia, political history consists of various problems, cause-effects and development of the Indonesian political landscape. Among the issues focused in the themes are: introducing public figures, inculcation of strong personality, understanding governmental systems and power structure, qualities of the leaders, political diplomatic relationship at the national and interpersonal levels and present mobility. Among the topics of historical stories discussed in class are about Indonesian freedom fighters, conflicts between the locals with the Dutch colony and the collapse of Suharto's regime power.

Social history discusses several themes including social problems and the spread of negative elements among Indonesian people. In addition, social history also discusses the society's lifestyle which then influenced the new generation in understanding various situations. Other than that, students are exposed to different education levels, security and welfare of local people. Other topics studied are related to continuation of societies and the restructuring process of Indonesian people.

Economics history focuses on lessons related to economics concepts, problems and economic implementation in Indonesia. It also discusses past events which are related to the Indonesian economy such as the development of agricultural activities and the spices business in the era of the Dutch East India Company and the Southeast Asia trade system.

Cultural history is about the lifestyle and cultures of the society and several communities. This includes the discussion about roles and relationship such as traditional customs, ritual and lifestyle of the Indonesian people. Cultural history is more interesting for the students and it is compulsory for students to understand cultural di- 
versity in Indonesia to promote mutual respects among people of different races. Wiriaatmadja (2002) maintains that, the national history taught in the Indonesian schools has the competencies to direct students to achieve the educational goals through the inculcation process, lessons and patriotic elements which develop students to be civilized and responsible human beings.

Intellectual history focuses on development of ideas and thinking methods which study the implications, spirit and values brought on from ideologists such as communism, capitalism and liberalism. The topics include the fascist and Nazi movement in Europe during the World War II, the spread and implementation of Marxism in Russia and the present capitalism bubble of the world. Hence, students learn about the positive and negative aspects of various ideologies.

\section{Problems and Challenges in Inculcating History Thinking Skills}

As teachers are responsible to inculcate History Thinking Skills (HTS) among students, it will be an obstacle if the teachers' knowledge is limited and their teaching depends solely on textbooks. Virta \& Kouki (2014) suggested that in-depth knowledge about history is not about knowing too much such as the ability to memorize years, names and recall countless events. Instead, it involves understanding and deeper analyzing of historical phenomena including flow of events or how history actually happened.

In reality, HTS is still not fully applied by teachers for their teaching and learning process, as the skill is considered as high thinking order and students have not yet mastered it. It is also difficult for students to interpret and analyze past events. It becomes a challenge for teachers to inculcate History Thinking Skill (HTS); hence they assume that students are incapable of having deep historical thinking (Snyder \& Snyder 2008). Without doubt, it is teachers whose concerns would create a great experience for students to think and analyze past events through the use of appropriate and suitable teaching aids.

It is beneficial for students to acquire History Thinking Skill (HTS); however, it is not easy to inculcate especially in a differentiated class with various levels of students' ability. For instance, it is difficult to inculcate History Thinking Skill (HTS) on students who have learning difficulty, particularly in understanding and thinking about complex issues in text books, facts bias and historical sources (Pearcy, 2014; Gaughan, 2014). History Thinking Skill (HTS) requires students to be all-rounder. They have to explore, study, analyze and interpret sources, link cause and effects based on historical events. In other words, students are required to have critical and creative thinking, together with other thinking criteria.

History subject is always referred to as a subject that requires one to memorize. Hence, that is the main issue brought forward by students and it is also blamed as the reason why many students do not like the subject and it is also considered as a boring mundane subject. In his studies, Kim (2000) has found that learning History normally focuses on the aspects of memorizing faces, dates and the world's turbulence happened thousands of years ago, causing students to have very narrow minded opinion on the process and nation development. A lot of students claimed history subject is boring and it fails to stimulate one to think. Ahmad, Awang, Seman, \& Abdullah (2013) have supported the statement with the same finding that the main focus of the subject is on memorizing; consequently students are not exposed to critical and creative thinking. Teaching history is traditional in a oneway manner which focuses mainly on teacher and it is not interactive. As a result, students are passive in the History class. The common scenario would be students sitting quietly to listen and copy notes provided by the teacher. Lecture style is commonly adopted as the main teaching technique.

Teachers have to manage the issues and problems related to the History subject teaching and learning process. This can effectively be done if teachers are ready to change their approach. In other words, teachers have to implement innovation in teaching and learning History subject in order to attain students' interests and simplify the delivery of historical facts for the students to easily digest the information. This in the long run would make the learning session to be interestingly alive.

\section{The Purpose of the Study}

The current study aimed at:

- identifying the level of historical thinking among teacher trainees in Malaysia and Indonesia;

- determining any significant difference of Historical thinking skills among teacher trainees in Malaysia and Indonesia based on gender;

- examining significant relationship between historical thinking skills of teacher trainees in Malaysia and In- 
donesia with their attitudes.

\section{Methodology}

This survey uses questionnaire as the instrument based on 5-point Likert scale to get information of the constructs being studied. A survey is used in this study as it enables for us to get data from a holistic view. Indeed, a survey allows us to get information from a random sample faster and cost effective. The questionnaire is used in this study to gather information from human participants. The constructs of the current study contains five main aspects namely chronologic skills, fact exploration skills, imagination skills, interpretation skills and rationalization skills (Ministry of Education, 2000). It was based on the History Curriculum as an official document in Malaysia (Ministry of Education, 2001; Curriculum Development Centre, 2001) and part of it was based on literature review; however, it was mainly adapted from previous studies by Yassin (2013), and Rashid (2000). To confirm face validity and content validity of the instrument, two experts on the History Education were consulted.

The questionnaire contains three main sections namely Demographic, Historical Thinking Skills and Student Attitudes towards Learning History. There are five main constructs for Historical Thinking Skills that are Chronology (6 items), Factual Exploration (5 items), Imagination (5 items), Interpretation (6 items), and Rationalizations (5 items). There are 15 items allocated for measuring Attitudes i.e. Chronology (3 items), Factual exploration (3 items), Imagination (3 items), Interpretation (3 items), and Rationalization (3 items).

A pilot study was conducted on 60 respondents, 30 Malaysian students and 30 Indonesian students respectively. The Alpha Cronbach scores were between 0.73 and 0.89 which informs high reliability of all items. A total of 260 respondents were recruited as samples, out of which 130 respondents are Malaysians and 130 are Indonesian students who are undergoing the History Education Program. They are year one and year three students for the 2014/2015 academic session. Unfortunately it was difficult to get equal number based on gender due to limited number of male students from both universities.

The majority of students are Year two students involving 69 respondents who are Malaysian students and 66 respondents who are Indonesians. To obtain the mean score, descriptive analysis was conducted, and MANOVA analysis was carried out for the inferential analysis. Interpretation of the mean scores was based on Ahmad (1993). The teacher's trainees' level of historical thinking skills and their attitudes are scored based on the following table (see Table 1).

Pearson correlation analysis was conducted to identify relationship between History Thinking Skills (HTS) in the aspects of chronologic skills, fact exploration skills, imaginative skills, interpreting skills and rationalizing skills, with the trainees' attitudes towards learning history. This includes how history thinking develops teachers' attitude in conducting history instructional process as well as teachers' attitude as moderators, facilitators and mediator in history learning. The strength of the relationship (see Table 2) is based on the correlation co-efficient as referred to by (Marican, 2005).

\section{Finding and Discussions}

A number of 260 respondents from Malaysia $(n=127)$ and Indonesia $(n=133)$ involved in this study. Table 3 shows demographic of the respondents involved in this study.

Females are found to be the majority of respondents in the comparative study of Historical Thinking in Malaysia and Indonesia. Data shows that there is a slight similar number of participants in Malaysia and Indonesia according to the genders and year of study.

\subsection{Level of Historical Thinking Skills (HTS) among Trainees of History Education Program at the Higher Learning Institutes in Malaysia and Indonesia}

To determine the level of Historical Thinking Skills (HTS) among students in Malaysia and Indonesia who are

\begin{tabular}{lc}
\hline Table 1. Interpretation of the mean scores. \\
\hline Mean score & Interpretation \\
\hline 3.67 to 5.00 & High \\
2.34 to 3.66 & Moderate/modest \\
1.00 to 2.33 & Low \\
\hline
\end{tabular}


Table 2. Interpretation of the correlation coefficient values.

\begin{tabular}{cc}
\hline Co-efficient & Interpretation/Description \\
\hline $0.00-0.09$ & can be ignored \\
$0.10-0.29$ & Low/poor \\
$0.30-0.49$ & Moderate/modest \\
$0.50-0.69$ & High/strong \\
$0.70-0.99$ & Very high \\
1.00 & Perfect \\
\hline
\end{tabular}

Table 3. Demographic profiles of the respondents.

\begin{tabular}{cccccc}
\hline Countries & \multicolumn{2}{c}{ Demographic } & $\mathbf{n}$ & $\mathbf{\%}$ & Total \\
\hline \multirow{3}{*}{ Malaysia } & Male & 49 & $38.5 \%$ & \\
& & Female & 78 & $61.4 \%$ & \\
& Year of study & Second & 55 & $43.3 \%$ & 127 \\
& & Third & 75 & $59.0 \%$ & \\
Gender & Male & 64 & $48.1 \%$ & \\
& & Female & 69 & $51.9 \%$ & \\
& & Second & 53 & $39.8 \%$ & \\
& Year of study & Third & 80 & $60.2 \%$ & \\
\hline
\end{tabular}

undergoing the History Education Program, descriptive analysis was conducted and recorded in Table 4:

Table 4 shows the overall results of the level of historical thinking skills among teacher trainees in Malaysia and Indonesia. Teacher trainees in Malaysia have higher competency in several skills namely fact exploration skill, imagining, interpreting and rationalizing historical events. However, Indonesian teacher trainees have higher competency in imaginative skills. Hence, it can be concluded that Malaysian students have higher tendency to use the thinking aspects in history subject by understanding critical and imaginative thinking in the life aspects of ancient people until today's generation (Curriculum Development Centre, 2002). Students' ability to imagine past events will enhance the process of learning history, making it more interesting (Seixas, 1996; Tsai, 2012). Based on a research finding by Chapman, Forster, \& Buchanan (2013) learning with imagination is normally influenced by students' national identity and personal experience which help students to link them with historical events.

The overall findings showed that trainees from both countries are aware of the importance of historical thinking skills in handling the process of learning to teach. Due to that, Kumalasari (2005) attributed problems in learning history to insufficient chance given to students to know their own strong personality through interpretation and imagination processes as it is believed that history should be explored, and the lesson would be meaningless if it involves only notes taking on important data and then kept securely.

It is found that all future teachers who are undergoing the training for history education in Malaysia have shown high skill level in all aspects of history thinking. This is in line with the requirement by the Malaysian government that History subject is a core and compulsory subject, thus putting it as an important and significant subject within students' achievement. According to Aziz \& Azleena (2007) it is important for teachers to stimulate students' thinking especially during the instructional process. These findings suggest that it is more important in the History subject as it involves abundance of stories, indicators of social changes as well as social development. Hence, teachers' training is the best platform to strengthen thinking skills before the pre-service teachers start their teaching service at schools (Celuch, Bourdeau, \& Smothers, 2014). 
Table 4. The level of historical thinking skills (HTS) among trainees of history education program at the higher learning institutes in Malaysia and Indonesia.

\begin{tabular}{|c|c|c|c|c|c|c|}
\hline \multirow{2}{*}{ Skills } & \multicolumn{3}{|c|}{ Malaysia } & \multicolumn{3}{|c|}{ Indonesia } \\
\hline & Mean & Standard deviation & Interpretation & Mean & Standard deviation & Interpretation \\
\hline Chronology & 3.61 & 0.40 & Moderate & 3.63 & 0.43 & Moderate \\
\hline Fact exploration & 3.74 & 0.46 & High & 3.60 & 0.45 & Moderate \\
\hline Imagination & 4.14 & 0.48 & High & 3.99 & 0.51 & High \\
\hline Interpretation & 3.69 & 0.59 & High & 3.55 & 0.43 & Moderate \\
\hline Rationalization & 3.75 & 0.43 & High & 3.63 & 0.47 & Moderate \\
\hline Overall & 3.78 & 0.36 & High & 3.68 & 0.35 & High \\
\hline
\end{tabular}

\subsection{Comparison of History Thinking Skills Owned by Teacher Trainees in Malaysia and Indonesia Based on Gender}

To identify the gender difference of history thinking skills owned by teacher trainees who are undergoing the history educational program at the higher learning institutes in Malaysia and Indonesia, MANOVA analysis was conducted. The value of Box's $M=32.807$ and sig $=0.008(p>0.001)$. As the variance-covariance of the dependent variables is homogeneous across the independent variables, this allows for the MANOVA test to be conducted.

Table 5 shows there is a significant difference of history thinking skills in the chronologic aspect based on gender among trainees in Malaysia and Indonesia with the $\mathrm{F}$ value $=6.805$ and sig $=0.010(p<0.05)$. The result shows that chronologic skill is important and effective for students in understanding historical events. It can therefore be assumed that the information is delivered orderly and the historical schemes are structurally processed. Mahmood (1998) and Gaughan (2014) agreed that it is easier to understand history based on the context of phase, era or framework. A possible explanation for this might be that it enables students to evaluate critically on the development and changes that happened in the society and nation development.

The results show that there were no significant differences based on gender in the aspects of facts exploration, interpretation, imagination and rationalization of history thinking skill among students undergoing the history education $(p>0.05)$. Generally, Malaysian students have higher history thinking skills compared to Indonesian students. Results show an effective inculcation of the history thinking skills in the context of teaching and learning History in Malaysia. Female students from both countries have significantly higher level of history thinking skill than male students. Specifically, the level for imaginative skill is higher than other skills showing that students have the ability to visualize historical events mentally based on their own understanding and interpretation.

\subsection{Relationship between History Thinking Skills and Attitudes of Teacher Trainees Undergoing History Education Program at the Higher Learning Institutes in Malaysia and Indonesia}

The relationship between history thinking skills and attitudes of teacher trainees with regard to the implementation of thinking skills in the instructional process was studied. It is found that Malaysian students have moderate level of thinking components, whereas Indonesian students are poor or low in inculcating the element of history thinking imaginative component. However, the results showed that the teacher trainees are positive and ready to inculcate the elements of history thinking. According to Jenkins (1991), thinking process actually begins the moment the teacher conducts the induction set, asks questions and executes the whole teaching and learning process.

As can be seen from the Table 6, every construct of the History thinking skill in Malaysia and Indonesia has modest or moderate relationship with students' attitudes. However, the relationship with the imaginative aspect among Indonesian teacher trainees shows poor or low relationship with students' attitude. The findings of this 
Table 5. The level of historical thinking skills (HTS) among trainees of history education program at the higher learning institutes in Malaysia and Indonesia.

\begin{tabular}{|c|c|c|c|c|c|c|c|c|c|c|}
\hline $\begin{array}{l}\text { Historical } \\
\text { thinking skills }\end{array}$ & Gender & Country & $\mathbf{N}$ & Mean & SD & $\begin{array}{l}\text { Type III sum } \\
\text { of squares }\end{array}$ & Df & Chi-square & $\mathbf{F}$ & Sig. \\
\hline \multirow{4}{*}{ Chronology } & \multirow{2}{*}{ Male } & Malaysia & 49 & 3.73 & 0.44 & 1.147 & 1 & 1.147 & 6.805 & 0.010 \\
\hline & & Indonesia & 64 & 3.60 & 0.44 & & & & & \\
\hline & \multirow{2}{*}{ Female } & Malaysia & 78 & 3.53 & 0.36 & & & & & \\
\hline & & Indonesia & 69 & 3.67 & 0.42 & & & & & \\
\hline \multirow{4}{*}{ Fact exploration } & \multirow{2}{*}{ Male } & Malaysia & 49 & 3.74 & 0.45 & 0.707 & 1 & 0.707 & 3.468 & 0.064 \\
\hline & & Indonesia & 64 & 3.49 & 0.52 & & & & & \\
\hline & \multirow{2}{*}{ Female } & Malaysia & 78 & 3.74 & 0.47 & & & & & \\
\hline & & Indonesia & 69 & 3.70 & 0.35 & & & & & \\
\hline \multirow{4}{*}{ Imagination } & \multirow{2}{*}{ Male } & Malaysia & 49 & 4.16 & 0.39 & 0.343 & 1 & 0.343 & 1.406 & 0.237 \\
\hline & & Indonesia & 64 & 3.92 & 0.54 & & & & & \\
\hline & \multirow{2}{*}{ Female } & Malaysia & 78 & 4.13 & 0.53 & & & & & \\
\hline & & Indonesia & 69 & 4.04 & 0.48 & & & & & \\
\hline \multirow{4}{*}{ Interpretation } & \multirow{2}{*}{ Male } & Malaysia & 49 & 3.69 & 0.41 & 0.346 & 1 & 0.346 & 1.292 & 0.257 \\
\hline & & Indonesia & 64 & 3.48 & 0.51 & & & & & \\
\hline & \multirow{2}{*}{ Female } & Malaysia & 78 & 3.69 & 0.69 & & & & & \\
\hline & & Indonesia & 69 & 3.63 & 0.33 & & & & & \\
\hline \multirow{4}{*}{ Rationalization } & \multirow{2}{*}{ Male } & Malaysia & 49 & 3.75 & 0.36 & 0.009 & 1 & 0.009 & 0.042 & 0.839 \\
\hline & & Indonesia & 64 & 3.62 & 0.54 & & & & & \\
\hline & \multirow{2}{*}{ Female } & Malaysia & 78 & 3.75 & 0.47 & & & & & \\
\hline & & Indonesia & 69 & 3.65 & 0.40 & & & & & \\
\hline
\end{tabular}

study provide a new dimension and it is different from the dimension highlighted by Virta \& Kouki (2014) on students' need of the instrument to manage affective aspect particularly in promoting the emphatic value to students through the process of learning history.

\section{Implication, Limitation, Contribution and Suggestions}

The findings of this study has important and clear implications that History education training at the universities in Malaysia and Indonesia is effective in inculcating the elements of history thinking skills as well as training future teachers on the history thinking competency. This finding, while preliminary, suggests that History teachers in Malaysia and Indonesia are positively ready to inculcate all elements of history thinking skills.

The findings of the current study clearly supports the results found by a previous research conducted by Kumalasari (2005) that teachers have positive attitudes to inculcate history thinking elements in the instructional process of teaching History. However, it is possible that they have to face challenges such as ineffective teaching aids and approaches or students' complex thinking activities. Anyway, it is important for teachers to ensure history thinking skills are able to develop a sense of empathy among their students (Endacott, 2010; Virta \& Kouki, 2014).

Overall, the findings also show that the level of the trainee teachers' perspective is at moderate and high levels towards several aspects of history thinking skills (HTS) involving chorological skill, fact exploration skill, imaginative skill, interpreting skills and rationalizing skills. Hence, teachers have to go extra miles in order to improve their understanding on how to inculcate thinking elements and improve their ability to apply it through professional trainings. This is crucial because the process of teaching and learning history would be constructive if the teachers were productive (Wiriatmadja, 2002). 
Table 6. Pearson correlation analyses on the relationship between history thinking skills and attitudesof trainee students undergoing History Education Program at the higher learning institutes in Malaysia and Indonesia.

\begin{tabular}{ccccccc}
\hline & \multicolumn{7}{c}{ Attitudes of teacher trainees towards learning history } \\
\cline { 2 - 7 } Relationship & \multicolumn{7}{c}{ Malaysia } & r & Sig. & Interpretation \\
\cline { 2 - 7 } & Sig. & Interpretation & 0.551 & 0.000 & Moderate \\
Chronology & 0.557 & 0.000 & Moderate & 0.544 & 0.000 & Moderate \\
Fact exploration & 0.453 & 0.000 & Moderate & 0.279 & 0.000 & Poor/low \\
Imagination & 0.454 & 0.000 & Moderate & 0.455 & 0.000 & Moderate \\
Interpretation & 0.448 & 0.000 & Moderate & 0.554 & 0.000 & Moderate \\
Rationalization & 0.447 & 0.000 & Moderate & & &
\end{tabular}

Yassin (2013) agreed that history thinking skills (HTS) should be part of teacher's instructional process in delivering knowledge and interpret history. It should not be separated from knowledge, personality and thinking. In fact, the three are integrated components needed to develop effective and concrete actions. According to Endacott \& Brooks (2013), the effectiveness of teaching and learning history depend on how the teacher embeds thinking competency, pedagogy and intelligence to stimulate students' behaviors in interacting with past history and stories.

The findings of this study has revealed and may help us to understand the future of History subject teachers' readiness in inculcating history thinking skills during their training period. The skills are already acknowledged and shaped, thus they need to be applied in schools. Due to that, History teachers should have high commitment to promote and inculcate history thinking. It will naturally be done the moment the teachers start using teaching aids or asking students some questions during their interaction with visual or in responding questions as the activities are important to encourage and stimulate students' thinking and exploring historical materials.

It can thus be suggested that teachers need trainings continuously to improve their competency level particularly on the implementation of thinking concept in teaching. In addition, they have to focus and know how to interpret historical events, influence students to involve in discussion and interpret various visual aids as well as making mental images. According to Hamimi (2013), it is a challenge for History subject teachers to implement history thinking skills in the context of 21st century students. Apart from that, at present, schools are functioning well to promote thinking where students are guided to think about the learning materials that they have learned. In other words, the role of History subject is to develop students through a more active, progressive and productive trend of study. The current style of study is no longer passive as students are not passive receivers or recipients of information. According to Kim (2000) it is important to reconstruct historical events, making it more meaningful and to have clear relationship with today's life.

An implication of this study is the possibility that Historical thinking skills should be inculcated starting from the primary school level until the past events would become knowledge foundation and life values for today's people. Most historical events have significant impacts on people and the impacts are indeed valuable life lessons. According to Wineburg (2001), historical events are not static but rather their impacts continue to be part of people's life. Hence, it is important to understand history in order to understand one self and the world.

Early knowledge on history thinking skill would benefit young students and provide them with at least the basic aspects of history thinking skill. In 2014, Malaysia started to implement the new primary school curriculum for History subject. In addition, the year 4 textbook was revised to include thinking aspect as an important element in students' learning process. However, only the first part of the year 4 text book focuses on history thinking aspects, while other parts of the contents discuss the history and civic education. As they refer a lot to the textbook, History teachers at the primary schools do not apply the history thinking aspects. Nevertheless, teacher trainees of the History education program need exposure on ways to relate history thinking skills with other topics in the textbook. This is one of the ways to improve and encourage students to think and to apply the skills in their daily life.

Apart from that, contents of the training syllabus for History teachers need to be revised making it to be more relevant with the latest development in schools. It is suggested that the syllabus should consider personal views from prominent educators who are experts in the knowledge, skills and personality needed to be mastered by the trainees. Other than that, the syllabus or training contents should also refer to various findings of previous stu- 
dies on teacher training program. In addition, it is wise to remember that it takes a longer period of time to inculcate history thinking, it definitely will not happen in a short duration of time. The current time provided for History subject is too short to cover the whole syllabus. Thus, it is important to revise the duration of time for better and more effective implementation of history thinking skills. As the current study focuses on the skills and attitudes only, there is still limited evidence to explain how school environment affects students' attitudes towards learning history. Therefore, further study is required. In addition, the current study utilizes a survey research design that leads to the limitation of in-depth understanding on promoting historical thinking skills in teaching and learning. This informs the need of qualitative study in future.

\section{Conclusion}

The current study highlights the importance of historical thinking skills in teaching profession and compares pre-service teachers' abilities in carrying out learning activities to promote historical thinking skills, namely chronologic skill, fact exploration skill, imaginative skill, interpreting skill and rationalizing skill. Overall, the majority of respondents are found to have a high level of thinking skills. It is therefore possible to conclude that most pre-service teachers are competent enough to integrate the elements of historical skills in the lesson. Although, most Malaysian pre-service teachers are found to have higher level of historical thinking skills compared to Indonesian pre-service teachers, it does not mean that one is better than another. It shows how historical thinking skills are important for the teachers in both countries. As the study was aimed at the level of historical thinking skills, more research on social environment in teacher training institutes in both countries needs to be undertaken before it is more clearly understood. A deeper exploration on this aspect is very significant as social environment has a strong connection with teachers' competence in many things. Indeed, the institutional values, ethos and culture in both countries have to be taken into account as it plays a major contribution.

\section{References}

Adams, G. A., King, L. A., \& King, D. W. (1996). Relationships of Job and Family Involvement, Family, Social Support, and Work-Family Conflict with Job and Life Satisfaction. Journal of Applied Psychology, 81, 411-42.

http://dx.doi.org/10.1037/0021-9010.81.4.411

Ahmad, A. R., Awang, M. M., Seman, A. A., \& Abdullah, R. (2013). The Skills of Using History Textbooks in Secondary School. Asian Social Science, 9, 229-236. http://dx.doi.org/10.5539/ass.v9n12p229

Ahmad, J. (1993). A Survey on the Constrains in the Implementation of the New Sciences Curriculum at Secondary Schools, Kedah Malaysia. Unpublished Thesis, Malaysia: Universiti Kebangsaan Malaysia.

Andrews, T., \& Burke, F. (2007). What Does It Mean to Think Historically? AHA Perspectives, 45, 32-35.

Awang, M. M., Ahmad, A. R. \& Ali, M. M. (2013). Professional Teachers' Strategies for Promoting Positive Behaviour in Schools. Asian Social Science, 9, 205-211. http://dx.doi.org/10.5539/ass.v9n12p205

Aziz, Z., \& Azleena, N. (2007). A Survey on History Teachers Readiness to Inculcate History Thinking Skills among Students. Educational Journal, 32, 119-137.

Barton, K. C. (2012). History: From Learning Narratives to Thinking Historically. In W. B. Russell (Ed.), Contemporary Social Studies: An Essential Reader (pp. 109-139). Charlotte, NC: Information Age Publishing.

Benjafield, J. G. (1992). Cognition. Englewood Cliffs, NJ: Prentice Hall.

Benjamin, R. et al. (2013). The Case for Critical-Thinking Skills and Performance Assessment. USA: Council for Aid to Education

Brooks, S. (2013). Teaching for Historical Understanding in the Advanced Placement Program: A Case Study. The History Teacher, 47, 61-77.

Celuch, K., Bourdeau, B., \& Smothers, J. (2014). Thinking Innovatively about Teaching Innovation and Ideation: Getting Students to Think Differently. Journal of Research in Innovative Teaching, 7, 27-37.

Chapman, A., Forster, D., \& Buchanan, R. (2013). The Moral Imagination in Pre-Service Teachers’ Ethical Reasoning. Australian Journal of Teacher Education, 38, 131-143. http://dx.doi.org/10.14221/ajte.2013v38n5.8

Curriculum Development Centre (2001). Philosophy of National Education, Mission and Vision. Kuala Lumpur: Ministry of Education Malaysia.

Curriculum Development Centre (2002). New Syllabus for History Education Secondary School form 4 and 5. Kuala Lumpur: Ministry of Education Malaysia.

Dewey, J. (1910). How We Think (1991 ed.). New York: Prometheus Books. http://dx.doi.org/10.1037/10903-000 
Dewey, J. (1920). Reconstruction in Philosophy (1957 ed.). London: Beacon Press. http://dx.doi.org/10.1037/14162-000

Eggan, P. D., \& Kauchak, D. P. (2001). Strategies for Teachers: Teaching Content and Thinking Skills. Upper Saddle River, NJ: Prentice Hall.

Ekecrantz, S., Parliden, J., \& Olsson, U. (2015). Teaching-Research Nexus or Mock Research? Student Factors, Supervision and the Undergraduate Thesis in History. In D. Ludvingsson, \& A. Booth (Eds.), Enriching History Teaching and Learning (pp. 15-33). Sweden: Linkoping University.

Endacott, J., \& Brooks, S. (2013). An Updated Theoretical and Practical Model for Promoting Historical Empathy. Social Studies Research and Practice, 8, 41-58.

Endacott, J. L. (2010). Reconsidering Affective Engagement in Historical Empathy. Theory and Research in Social Education, 38, 6-47. http://dx.doi.org/10.1080/00933104.2010.10473415

Gaughan, J. E. (2014). The Flipped Classroom in World History. The History Teacher, 47, 221-244.

Hamimi, K. A. (2013). Sustainable Thinking Skills in History Education. History and Geography Education Seminar.

Jenkins, J. (1991). Issues in the Teaching History-Towards a Skill Concept-Led Approach. Journal of History Teaching, 64., 17-21.

Kartodirdjo, S. (1992). History Education and Human Development. Bandung: Sanata Dharma.

Kim, J.-K. (2014). Learning to Live Together. Bangkok: United Nations Educational, Scientific and Cultural Organization.

Kim, K. K. (2000). History Philosophy: Towards Developing Patriotism and Nationalisme Elements. National Seminar of Education Philosophy in Strengthening National Mission and Vision, Unversiti Malaya, Kuala Lumpur, 6-7 July, 16-26.

Kumalasari, D. (2005). History and Problems. Historia, 1, 7-22.

Mahmood, M. (1998). Analysis of History Thinking Skills in the Lower Secondary Schools Curriculum Materials. Postgraduate Thesis, Kuala Lumpur: Universiti Malaya.

Mansor, A. (2011). Pendidikan Sejarah Pengukuh Patriotism (History Education Strengthening Patriotisme). Harian Metro, 15 September.

Marican, S. (2005). Research Methods in Social Sciences. Kuala Lumpur: Prentice Hall/Pearson Malaysia.

Ministry of Education (2000). History Syllabus for Secondary School New Syllabus Form 1, 2, 3.

Ministry of Education (2001). Teaching and learning History Training Module. Kuala Lumpur: Curriculum Development Centre.

Noordin, W. Z. W. (1993). Education towards 2020. A Research Report. Kuala Lumpur: Malaysia Ministry of Education.

Pearcy, M. (2014). Student, Teacher, Professor: Three Perspectives on Online Education. The History Teacher, 47, $169-185$.

Rashid, A. R. A. (2000). Model and History Teaching Approach Kuala Lumpur. Kuala Lumpur: Dewan Bahasa danPustaka.

Rohlf, G. (2015). How to Make Field Trips Fun, Educational, and Memorable: Balancing Self-Directed Inquiry with Structured Learning. The History Teacher, 48, 517-528.

Salleh, M. J. (2003). History Curriculum for Secondary Schools: Students’ Perspectives. Working Paper for Centre of Education and Human Development, Islamabad: Islamic International University.

Schulze, J. L. (2014). The Ethnic Participation Gap: Comparing Second Generation Russian Youth and Estonian Youth. Journal on Ethnopolitics and Minority Issues in Europe, 13, 19-56.

Seixas, P. (1996). Conceptualizing the Growth of Historical Understanding. In D. R. Olson, \& N. Torrance (Eds.), The Handbook of Education and Human Development (pp. 765-783). Cambridge, MA: Blackwell Publishers Ltd.

Snyder, L. G., \& Snyder, M. J. (2008). Teaching Critical Thinking and Problem Solving Skills. The Delta Pi Epsilon Journal, 2, 90-99.

Sokolov, A. (2015). The Development of Students' Critical Thinking through Teaching the Evolution of School History Textbooks: A Case Study. In D. Ludvingsson, \& A. Booth (Eds.), Enriching History Teaching and Learning (pp. 85-100). Sweden: Linkoping University.

Sultan, M. (2000). Quality of History Teaching in Schools at Sabak Bernam District. Kuala Lumpur.

Swartz, R., \& McGuiness, C. (2014). Developing and Assessing Thinking Skills. Final Report of Thinking Skills Project. Boston \& Northern Ireland: The International Baccalaureate Organisation.

Tsai, K. C. (2012). Play, Imagination, and Creativity: A Brief Literature Review. Journal of Education and Learning, 1, 15-20. http://dx.doi.org/10.5539/jel.v1n2p15

Twells, A. (2015). "More than Gaining a Mark": Students as Partners and Co-Producers in Public History and Community Engagement. In D. Ludvingsson, \& A. Booth (Eds.), Enriching History Teaching and Learning (pp. 51-66). Sweden: Linkoping University. 
Virta, A., \& Kouki, E. (2014). Dimensions of Historical Empathy in Upper Secondary Students’ Essays. NordidacticaJournal of Humanities and Social Science Education, 2, 137-160.

Wineburg, S. (2001). Historical Thinking and Other Unnatural Acts: Charting the Future of Teaching the Past (Critical Perspectives on The Past). Philadelphia, PA: Temple University Press.

Wiriatmadja, R. (2002). History Education in Indonesia: Local, National and Global Perspectives. Bandung: Historia Utama Press.

Yassin, Z. M. (2013). Evaluation of History Thinking Inculcation Process at the Upper Secondary Schools. Doctorate Thesis, Bangi: Universiti Kebangsaan Malaysia. 